\title{
In Vitro Screening of Bacillus Isolates for Biological Control of Early Blight Disease of Tomato in Shambat Soil
}

\author{
Saifeldeen A. Abdalla ${ }^{1}$, Soad A. A. Algam², Elshiekh A. Ibrahim³, Ahmed M. El Naim ${ }^{3, *}$ \\ ${ }^{1}$ Department of Plant Protection, Faculty of Natural Resources and Environmental Studies, University of Kordofan, Elobied, Sudan \\ ${ }^{2}$ Department of Plant Protection, Faculty of Agriculture, University of Khartoum, Khartoum, Shambat, Sudan \\ ${ }^{3}$ Department of Crop Sciences, Faculty of Natural Resources and Environmental Studies, University of Kordofan, Elobied, Sudan \\ *Corresponding author: naim17amn@yahoo.com
}

Received December 14, 2013; Revised March 06, 2014; Accepted March 09, 2014

\begin{abstract}
Rhizosphere bacteria are one of the most potential biological control agents in the plant disease protection. Bacillus species as a group offer several advantages over other bacteria for protection against pathogens because of their ability to form endospores, and because of the broad-spectrum activity of their antibiotics. Five soil samples from tomato rhizosphere were collected from shambat area, Khartoum State, Sudan. Bacillus isolates were isolated from the rhizosphere of tomato to use as natural bio-control agents. They were screened for antagonism in vitro against Alternaria alternata causal agents of early blight disease of tomato. Serial dilution technique was adopted for the isolation of Bacillus species. Only 27 out of 45 Bacillus isolates showed antagonistic properties. Four out of the 27 isolates showed antagonism (Bacillus B25, B35, B41, B45) were identified to the species level by bacteriological assay (morphological and biochemical tests).
\end{abstract}

Keywords: biological control; Bacillus spp., Alternaria alternate, tomato, early blight

Cite This Article: Saifeldeen A. Abdalla ${ }^{1}$, Soad A. A. Algam, Elshiekh A. Ibrahim, and Ahmed M. El Naim, "In Vitro Screening of Bacillus Isolates for Biological Control of Early Blight Disease of Tomato in Shambat Soil.” World Journal of Agricultural Research, vol. 2, no. 1 (2014): 47-50. doi: 10.12691/wjar-2-2-3.

\section{Introduction}

Tomato (Solanum lycopersicum L. [Peralta et al. 2005 Syn. Lycopersicn esculentum (Mill.)], is one of the widely cultivated food crops, it belongs to the important fruit vegetables for human nutrition and is cultivated across all continents in fields or in protected culture. Diseases caused by Alternaria are among the most common diseases of many kinds of plants throughout the world. They affect primarily the leaves, stems, flowers, and fruits of annual plants, especially vegetables, citrus and apple. Early blight of tomato caused by Alternaria solani (Ellis and Martin) Jones and Grout, is one of the most common and destructive diseases of tomato in the areas of heavy dew, rainfall and relative humidity. The disease becomes wide spread and serious, causing large economic loss to the growers when the season begins with abundant moisture or frequent rains followed by warm and dry weather which are unfavorable for the host and help in rapid disease development (Agrios, 1988) [1]. The fungus can cause disease on foliage (leaf blight), stem (collar rot) and fruit, and can result in severe damage during all stages of plant development [2]. The leaf blight phase, commonly referred to as early blight, is the most important phase of the disease and can result in complete loss of the crop when incidence is severe [3]. High humidity and the ineffectiveness of fungicides due to frequent heavy rainfall increases the disease intensity. Even under irrigated conditions, susceptible hybrids can be severely damaged by early blight incurring a loss of 50 to $80 \%$ [4].

Alternaria diseases appear usually as leaf spots and blights, but they may also cause damping - off of seedling, stem rots, and tuber and fruit rots. One of the most important diseases caused by Alternaria is the early blight of potato and tomato [5]. Early blight is a serious disease of tomato, it causes loss in yield is ranged from 5-78\% [6]. Alternaria alternata was reported also in the dry areas of Northern Sudan (annual rainfall between 0 - $300 \mathrm{~mm}$ ). In intensive agricultural production systems, protection against biological factors which adversely influence the efficiency of cultivation and the microbiological quality of crops as raw materials is of great significant. Owing to the emergence of sustainable agriculture, the protective methods available have been reassessed in the past decade. The importance of using environment-friendly and foodhygienically-safe plant-protecting methods, and plantprotecting agents of biological origin, has been greatly emphasized. Several members of the genus Bacillus, including Brevibacillus and Paenibacillus species, produce various antimicrobial substances, e.g. antibiotics. Being capable of producing more than 70 different antibiotics, B. subtilis is one of the major producers of these substances in the genus. Brevibacillus (formerly known as Bacillus) 
brevis is also characterized by its capability to produce antibiotics. In addition, a wide range of antimicrobial substances are produced by B. licheniformis, B. pumilus, B. circulans, B. cereus, Brevibacillus laterosporus, Paenibacillus (formerly Bacillus) polymyxa and other species $[7,8,9,10]$. Although agro-chemicals are the most effective and immediate solution to most disease problems, might accelerate degradation of ecosystems and induce pathogens resistance. Moreover, persistent residues will cause health problems to human beings. Biological control using microorganisms to suppress plant disease, offers a powerful alternative to the use of synthetic chemicals [11], [12]. Bacillus spp. are non pathogenic, good secretors of proteins and metabolites, and easy to cultivate. Products currently available commercially include enzymes, antibiotics, and insecticides [13]. The control of tomato early blight disease has been almost exclusively based on the application of chemical fungicides. Several effective fungicides have been recommended for use against this pathogen, but they are not considered to be long-term solutions, due to concerns of expense, exposure risks, fungicide residues and other health and environmental hazards. In an attempt to modify this condition, some alternative methods of control have been adopted. Recent efforts have focused on developing environmentally safe, long lasting and effective bio-control methods for the management of plant diseases. Use of bio-control agents has been shown to be eco-friendly and effective against many plant pathogens. Therefore, bio-control agents may provide a seemingly environmental friendly alternative to potent and toxic fungicides, which cannot be broken down in the environment. The aim of present study is to test the in vitro bio-control abilities of bacterial agents Bacillus isolate on A. alternate causal agent of tomato early blight disease.

\section{Materials and Methods}

\subsection{Isolation of the Fungus in Pure Culture}

Infected leaves of tomato plants displaying the characteristic symptoms of early blight disease were collected in winter (2008) from Shambat area. Each of the diseased leaves was cut into small pieces (5-10 $\mathrm{mm}$ ), washed with distilled water and surface sterilized with mercuric chloride (conc. 0.1\%) for two minutes. Then sterilized tissues were rinsed several times in sterilized distilled water and dried. Four pieces were transferred with sterilized needle (flamed on Bunsen burner) and distributed on PDA medium in $9 \mathrm{~cm}$ Petridishes and then incubated at a temperature of $27^{\circ} \mathrm{C}$ and left to grow for 7-10 days. After suitable growth of the fungus, pure cultures were made on new media.

\subsection{Source of Potentially Antagonistic Bacteria}

Five soil samples as a good source of antimicrobially active Bacillus species were taken from tomato rhizosphere collected from Shambat area. All the samples were cooled to $4^{\circ} \mathrm{C}$ so that any change in the original microflora would be prevented. The weight of individual samples was $100 \mathrm{~g}$.

\subsection{Isolation of Antagonistic Bacteria}

Serial dilution technique was used for isolation of Bacillus from the rhizosphere soil samples. One gram of air-dried soil samples were weighted and suspended in 9 $\mathrm{ml}$ of sterilized distilled water and shacked well. Amount of $1 \mathrm{ml}$ of the soil suspension at $10^{5}, 10^{6}, 10^{7}$ dillution was spreaded on each Petri plates of NA (Nutrient Agar) medium and the plates were incubated at $30^{\circ} \mathrm{C}$ for $48 \mathrm{hrs}$. Bacillus colonies were picked from the medium and sub cultured on freshly prepared slant tubes of NA agar medium at 3-monthy intervals.

\subsection{In Vitro Screening of Antagonistic Bacteria}

Antagonistic activity of Bacillus isolates on Alternaria alternata were carried out according to the agar diffusion method as described by Pajand and Paul [14]. The radius of the inhibition zones was measured. The fungus was tested as a plug of mycelium at the center of a Petri dish (9 $\mathrm{cm}$ ) of half-strength PDA using sterile cork porer 0.78 $\mathrm{mm}$ in diameter, Bacterial isolates spotted on to the agar near the outer edge of the dish. Sterile toothpicks were used to transfer the test isolates of Bacillus from 2-days old cultures. Plates were incubated at $27^{\circ} \mathrm{C}$ and inhibition zones were measured after 7-days. All bacterium-fungus combinations were replicated on three plates. Only those isolates that produced a clear inhibition zone were considered effectively [15].

The experiment was laid at a completely randomized design (CRD) with three replications. Data were analyzed statistically using analysis of variance according to Gomez and Gomez [16] procedure for a completely randomized design. The differences of means were identified by Duncan's Multiple Range Test (DMRT)

\section{Results and Discussion}

Forty five Bacillus isolates were tested for their efficacy in inhibiting growth of A. alternate. Twenty seven of them were considered as effective (showed clear inhibition zone). This suggests that the 27 isolates of Bacillus displayed antagonism against $\mathrm{A}$. alternata in-vitro, due to the production of antimicrobial compounds. Analysis of variance (Table1) showed high significant differences among the treatments (27 isolates and the control). The inhibitory zones were ranged from $2.0 \mathrm{~cm}$ to $3.4 \mathrm{~cm}$ in diameter (Table 2). Four isolates showed high inhibitory effect on the pathogen. B35 exhibited the highest inhibition $(3.4 \mathrm{~cm})$, followed by the isolates B25, B42, and B41 which recorded inhibition zone of 3.3, 3.1, and $3.1 \mathrm{~cm}$, respectively (Table 2 and Figure 1). In this study, 27 Bacillus isolates were selected out of 45 from tomato rhizosphere caused inhibition of the mycelia growth of A. alternata. This suggests that the 27 isolates of Bacillus displayed antagonism against A. alternata in-vitro, due to the production of antimicrobial compounds. The efficient antibiotic-producing bacterium could be used for biological control of plant diseases carried by many workers. Isolates of Bacillus spp., on agar plates, produced a zone of inhibition, an area of browning of the pathogens, or grew rapidly over the pathogen and inhibited their growth [17]. Bacterial bio-control agents belonging to the genera Agrobacterium, Bacillus, Pseudomonas, and 
Streptomyces, have been found by observing zones of inhibition in Petri plates [18]. These results are in agreement with our results. Bacillus spp. isolates have shown the capacity to control early leaf spot of peanut [19], yam leaf spot [20], grey mould of strawberries [21], and post-bloom fruit drop of citrus [22], which support our results. The results of Abou-Zeid et al [23] indicatedthat the antibiotics produced by the antagonists were more effective than the bacteria itself and differ with different bacteria. Pengnoo et al. [24] found that 16 isolates of Bacillus spp. had the ability to inhibit mycelial growth of Rhizoctonia solani, causal agent of leaf blight of bambara groundnut. Among these isolates, Bacillus firmus had the greatest activity in anti-microbial tests against Rhizoctonia solani. On the other hand Essam et al. [25] found that Bacillius subtilis 1020 and B. cereus 1080 showed highest antifungal activity against the pathogen, Penicillium italicum. Yazici et al [26]) reported that several bacteria such as $B$. subtilis (IK-83, IK-92 and IK159), B.cereus-GC subgroup $A$ (IK-34) and $B$. amyloliquefaciens (IK-104) were very effective against $A$. solani in vitro tests.

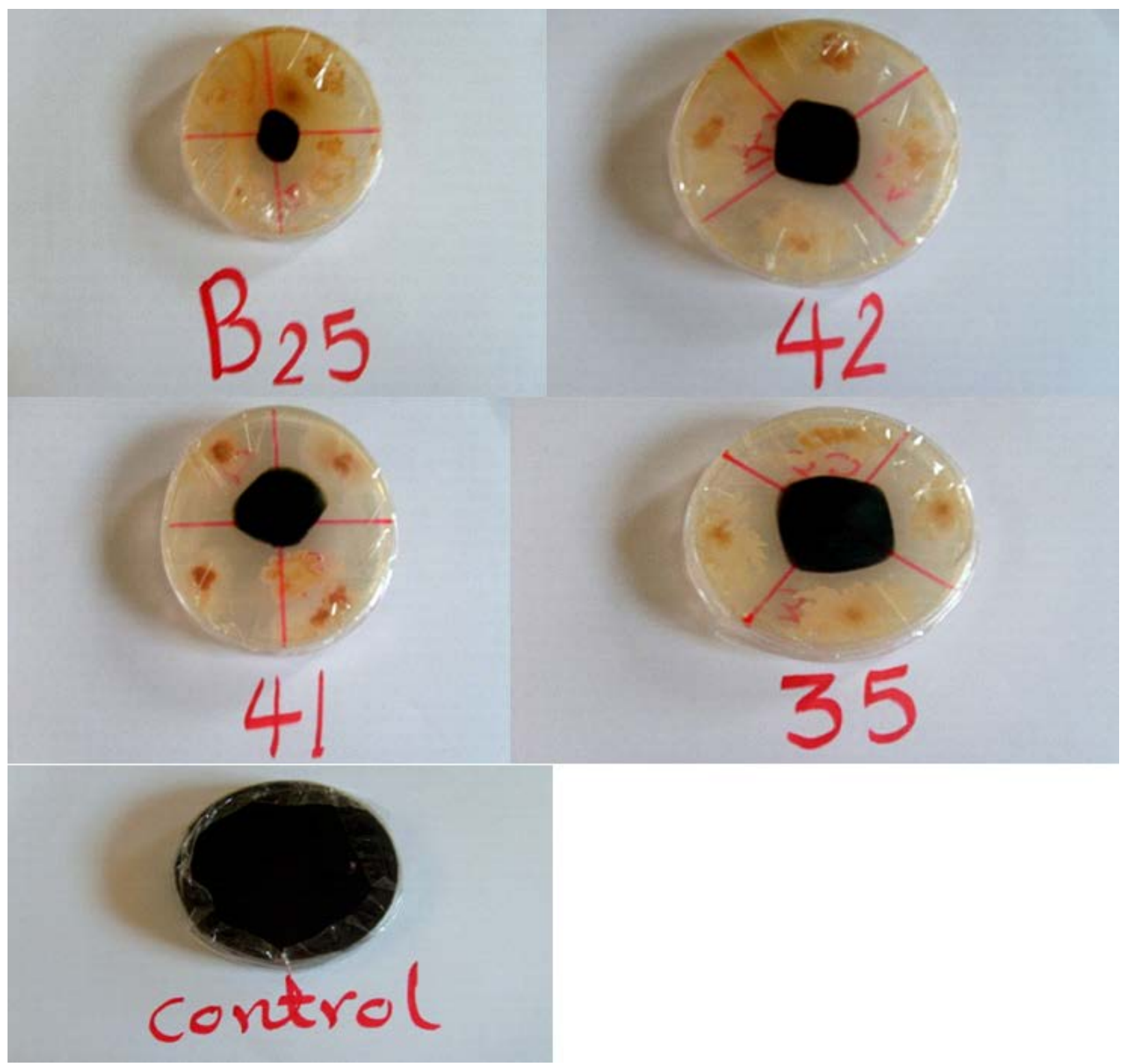

Figure 1. Examples in vitro inhibition assay. Different Bacillus isolates [B25, B35, B41, and B45] are tested for their ability to inhibit the growth of A. alternata. Zones of growth inhibition can be detected around bacterial strains

Table 1. Mean square for growth inhibition zone of twenty seven Bacillus isolates and control (untreated)

\begin{tabular}{|c|c|c|}
\hline Source of variation & D.f & Mean Square \\
\hline Treatment & 27 & $1.096^{* *}$ \\
\hline Error & 56 & 0.039 \\
\hline
\end{tabular}

\footnotetext{
** denotes significant at 0.01 level of significance
} 
Table 2. Growth inhibition zone induced by Bacillus isolates on Alternaria alternata

\begin{tabular}{|c|c|c|}
\hline Isolates & Diameter of inhibition zone $(\mathrm{cm})$ & \% inhibition \\
\hline B2 & 2.9cde & 64.4 \\
\hline B3 & 2.8cdef & 62.2 \\
\hline B4 & $2.0 \mathrm{~h}$ & 44.4 \\
\hline B5 & $2.5 \mathrm{fg}$ & 55.6 \\
\hline B6 & 2.3gh & 51.1 \\
\hline B7 & 3.0bcd & 66.7 \\
\hline B8 & 3.0bcd & 66.7 \\
\hline B9 & 2.9cde & 64.4 \\
\hline B10 & 3.1abc & 68.9 \\
\hline B11 & 2.9cde & 64.4 \\
\hline B14 & $2.7 \mathrm{def}$ & 60.0 \\
\hline B15 & 2.7def & 60.0 \\
\hline B16 & 2.8cdef & 62.2 \\
\hline B17 & 3.0bcd & 66.7 \\
\hline B18 & 3.0bcd & 66.7 \\
\hline B20 & 3.0bcd & 66.7 \\
\hline B23 & 3.0bcd & 66.7 \\
\hline B25 & 3.3ab & 71.7 \\
\hline B29 & 2.6efg & 57.8 \\
\hline B31 & $2.5 \mathrm{fg}$ & 55.6 \\
\hline B32 & 2.9cde & 64.4 \\
\hline B35 & $3.4 \mathrm{a}$ & 75.6 \\
\hline B36 & 2.8cdef & 62.2 \\
\hline B39 & 2.8cdef & 62.2 \\
\hline B41 & 3.1abc & 68.9 \\
\hline B42 & 3.1abc & 68.9 \\
\hline B44 & 2.8cdef & 62.2 \\
\hline Control & $0.0 \mathrm{i}$ & 0.0 \\
\hline
\end{tabular}

Means with the same letter within a column are not significantly different, at 0.05 level of significance, according to Duncan Multiple Range Test

\section{Conclusion}

The four selected isolates (B25, B35, B41, and B45) which had antagonistic activity against $A$ alternata will be further evaluated as potential bio-control agent for control of early blight disease in tomato. Also further field studies must be conducted to analyze the real potential of these bacterial agents in the field conditions. Studies are also needed to determine the modes of action of those bacteria, the population density of the applied bacteria, and the best form of introduction into the host.

\section{References}

[1] Agrios, G.N., "Plant pathology", Academic Press Limited 24-28 oval, London NWI, 7DX, 1988, p. 803.

[2] Nash, A.F., Gardner, R.G, "Tomato early blight resistance in a breeding line derived from Lycopersicon hirsutum PI 126445”. Plant Dis. 72, 206-209. 1988.

[3] Kallo, G., Banerjee, M.K, "Early blight resistance in Lycopersicon esculentum Mill. Transferred from L. pimpinellifolium (L.) Mill. and L. hirsutum f. glabratum Mull”, Gartenbauwiss, 58: 238-240, 1993.

[4] Mathur, K., Shekhawat, K.S, "Chemical control of early blight in kharif sown tomato”, Indian J. Mycol. Plant Pathol, 16 (2), 235236, 1986.
[5] Agrios, G.N, "Plant pathology", 3rd edition. Academic Press, New York. U.S.A., 1997.

[6] Fontem, D.A., Cameron, R., Opena, R.T., Gumedoe, Y.D, "Impact to blight infection tomato yield". TVIS Newsletter. www.libuts.avrdc.org.tw/fultext-pdf. 1996; accessed on 04/06/2008.

[7] Katz, E., Demain, A.L, "The peptide antibiotics of Bacillus: chemistry, biogenesis, and possible role”, Bacteriological Reviews, 41, 449-474, 1977.

[8] Shoji, J., "Recent chemical studies on peptide antibiotics from the genus Bacillus”, Advances in Applied Microbiology, 24, 187-214, 1978.

[9] Peralta, I.E., Knapp, S., Spooner, D.M., "New species of wild tomatoes (Sola, num section Lycopersicon: Solanaceae) from Northern Peru”. Sys Bot., 30, 424-434, 2005.

[10] Foldes, T., BaÂnhegyi, I., Herpai, Z., Varga, L., Szigeti, J., "Isolation of Bacillus strains from the rhizosphere of cereals and in vitro screening for antagonism against phytopathogenic, foodborne pathogenic and spoilage micro-organisms", Journal of Applied Microbiology, 89, 840-846, 2000.

[11] Howarth, F.G., "Environmental impact of classical biological control”, Annu. Rev. Entomol; 36: 485-509, 1991

[12] Osburn, R.M., Milner, J.L., Oplinger, E.S, Smith, R.S. Handelsman, J., "Effect of Bacillus cereus U W 85 on the yield of soypean at two field sites in Wisconsin", Plant Dis., 79, 551-556. 1995.

[13] Luna, C.L.R., Mariano, R.L., Souto-Maior, A.M., "production of a biocontrol agent for crucifer's blach rot disease”, Braz. J. Chem. Eng., 19, 2, 2002.

[14] Pajand, N., Paul, A.J., "Endophytic Bacteria Induce Growth Promotion and Wilt Disease Suppression in Oil seed Rape and Tomato", Biological Control, 18: 208-215, 2000;

[15] Algam, SA. E., "Biological Control of Bacterial Wilt of Tomato in Greenhouse Environment by Bacillus spp. Isolated from Tomato Rhizosphere”, Ph.D thesis, Zhejian University, 2005.

[16] Gomez, K.A., Gomez, A.A., "Statistical for Agricultural Research”. John. Wiley and Sons. New York, 1984.

[17] Franicevic, S.C., "Biological control of Botrytis cinerea and Sclerotinia sclerotiorum on kiwifruit”. ResearchSpace@Auckland. http://hdl. Handle. Net/2292/1971. 1993.

[18] Larkin, R.P., Farvel, D.R., "Efficacy of various fungal and bacterial bio-control organisms for control of Fusarium wilt of some vegetables”, Plant Dis., 82: 1022-1028. 1998.

[19] Kokalis-Burelle, N., Backman, P.A., Rodriguez-Kabana, R., Ploper, L.D., "Potential for biological control of early leaf spot of peanut using Bacillus cereus and chitin as foliar amendments", Biol. Control, 2: 321-328. 1992.

[20] Michereff, S.J., Silveira, N.S.S., Reis, A., Mariano, R.L.R, "Epiphytic bacteria antagonistic to Curvularia leaf spot of yam", Microbiol. Ecol., 28: 101-110. 1994.

[21] Swadling, I., Jeffries, R.P., "Isolation of microbial antagonists for biocontrol of gray mould disease of strawberries”, Bio-control Science and Technology, 6. 1996.

[22] Sonoda, R.M., Guo, Z.T., Nemec, S., "Effect of spray applications of Bacillus subtilis on postbloom fruit drop of citrus", Phytopathology, 86. S52- S53. 1996.

[23] Abou-Zeid, A.M., Altalhi, A.D., Abd El-Fattah, R.E., "Bacterial control of pathogenic fungi isolated from some wild plants in Taif Governorate, Saudi Arabia”, Mycopath, 7 (1).11-20. 2009.

[24] Pengnoo, A., Wiwattanapattapee, R., Chumthong, A., Kanjanamaneesathian, M., "Bacterial antagonist as seed treatment to control leaf blight disease of bambara groundnut (Vigna subterranean)", World J. Microbiol. Biotechnol. 22. 9-14. 2006.

[25] Essam, A.A., Soad, M.A.S., Mostafa, A.E.S., Mervat, F.F., "Toward the biological control of post harvest blue mold of Citrus sinensis fruits in Egypt. I- Isolation and characterization of antagonistic strain of Streptomyces alni”, Pak. J. Biolog. Sci., 9. 2945-2956. 2006.

[26] Yazici, S., Yanar, Y., Karaman, I., "Evaluation of bacteria for biological control of early blight disease of tomato". African Journal of Biotechnology, 10 (9). 1573-1577. 2011. 